\title{
MEASUREMENT OF PARTICIPATION LEVELS OF WOMEN AND MINORITIES AS COLLEGIATE AVIATION EDUCATORS
}

\author{
Dr. Brent D. Bowen \\ Associate Director \\ National Institute for Aviation Research \\ wichita State University \\ Wichita, Kansas
}

\section{ABSTRACT}

This study analyzes U.S. Department of Education statistics on women and minorities in higher education and data on Federal Aviation Administration (FAA) certificate holders. This data is then compared to data obtained on aviation faculty in higher education to establish whether or not women and minorities are under represented in the collegiate aviation faculty.

The data collected demonstrates that the participation of women in the aviation faculty is representative of the participation of women in aviation overall. The fact that women comprise only 6.09 percerit of all FAA certificated pilots demonstrates that they are as a group, under represented in aviation in relation to their proportion in society.

Minority participation in the collegiate aviation faculty is also unrepresentative of the minority population in the United states. FAA certificate data is not maintained on ethnicity. However, data obtained on minority participation in the aviation faculty is compared to data on minority participation in higher education. The resulting fact is that minority involvement in the aviation faculty is below average in relation to the overall faculty population.

This research effort confirms the assumption that women and minorities are not adequately represented in the collegiate aviation faculty. The resulting call to action must be to increase the participation levels of women and minorities as collegiate aviation educators. 


\section{INTRODUCTION}

American society has made some progress in accepting women and minorities in the work place. Successes are visible in many careers. Achievement is evident in all. However, encouragement for women and minorities to participate in aviation has not paralleled these successes.

The history of women and minorities in aviation exemplifies significant contributions too numerous to detail within the scope of this study. However, the time has come to consider the accomplishments that could have been achieved if women and minorities had been fully enfranchised into the field of aviation. This problem is especially evident among the ranks of pilots and those who educate pilots.

American Demographics (Nov. 1989) describes the phenomena of under representation by women as a "demographic wild card" which can be utilized to put more pilots in the sky. The successes which women and minorities have had in other fields has allowed increased access to flight careers.

The opportunity to become a professional aviator has never been more accessible than now. The General Aviation Task Force reports that flight instruction increased 12.5 percent in 1989 . student pilot starts in september 1989 were 10,153 compared to 7,624 the preceding year (More student Pilots, 1990). This influx may be attributed to the widespread news that more than one-half of all airline captains will reach mandatory retirement age before the year 2000. Combine this with the fact that military pilot attrition rates have slowed to record lows and thus the career potential becomes obvious.

The material presented here is of a narrow focus to the overall problem of under representation of women and minorities in aviation. Although, this endeavor will be successful if it allows any improvement in the awareness of this problem and, consequently, addresses even one aspect of its solution.

\section{WHY ARE WOMEN UNDER REPRESENTED IN AVIATION}

Under representation in aviation by women is generally agreed to be synonymous with that of other careers which have been nontraditional for women. The FAA is circulating a monograph titled Women in Aviation and Space written by Dr. Sandra Flowers of the Alabama Aviation and Technical college which addresses this question. Possible reasons for under representation, as suggested by Dr. Flowers, are as follows:

1. Cultural and psychological barriers to nontraditional work are imposed on women, not only by society, but by 
women themselves.

2. Women have not received the necessary information and training they need to prepare for nontraditional careers. 3. Nontraditional role models are few in number and are not readily available to girls and women.

4. The lack of support from family and peers negatively affects nontraditional career options for women.

5. Sex-role stereotyping in all types of media precludes an environment which supports nontraditional career choices and role models.

This clearly establishes the basis for concern. Defining the problem of under representation is certainly as complex as determining the solution. Neither can be appropriately addressed in the brevity of this forum. However, the analysis of the data to be presented may foster a greater understanding which may lead to a solution to some aspect of this problem.

\section{MINORITY REPRESENTATION IN AVIATION}

The participation of minorities in aviation is difficult to gauge. The FAA does not gather data on the ethnic background of certificate holders (Beardsley, 1990). This fact complicates the measurement of minority representation in aviation and consequently prevents the identification of success and failure. However, it is generally accepted that minorities are under represented in aviation.

The FAA recently released a publication titled, The Historically Black Colleges and Universities Program. Through this program the FAA plans to encourage and support minority participation in aviation. To facilitate this endeavor the FAA will encourage minority participation in the Airway science Curriculum Program, Research Contract opportunities, and Training and Internship Programs.

Comparison between two airline pilot professional organizations may offer an indication of minority participation within commercial aviation. The organization which represents airline pilots is the Air Line Pilot's Association. This organization has a reported membership of 42,000 (Mazor, 1990). The urganization representing black airline pilots, the Organization of Black Airline Pilots, reports a membership of 650 (Hadden, 1990).

\section{STUDY DESIGN}

The principal objective of this report is to determine the level of participation of women and minorities in the nonengineering aviation faculty. Data will be analyzed to determine the potential similarity between the number of women pilots and the 
number of women faculty in colleges and universities which offer a baccalaureate degree in aviation. This analysis is not possible with the minority population because the FAA does not maintain certificate data categorized by ethnicity. However, data obtained on the number of women and minority faculty in aviation will be analyzed against data on the number of women and minorities receiving earned doctorates in aviation related fields.

Secondary data was obtained from two sources. Data on the number of women who are pilots was obtained from the FAA which publishes an annual summary of pilot demographics titled U.S. Civil Airmen statistics. The data on women and minorities receiving doctoral degrees is periodically collected by the U.S. Department of Education. This information is reported annually in The Chronicle of Higher Education Almanac and the Digest of Education statistics. These sources can be regularly reviewed to monitor the progress toward achieving proportional representation for women and minorities in both of these areas.

Primary data on women and minority faculty in collegiate aviation programs was obtained through a survey of baccalaureate degree granting institutions listed in the collegiate Aviation Directory 1989. Each of the sixty-nine institutions which cited baccalaureate degree programs were contacted and asked to report the number of full-time faculty which teach aviation courses distinguishing the total number of males, the total number of females, and the total number of minorities. Sixty-five of sixtynine institutions responded for a response rate of 94 percent.

\section{PRESENTATION OF DATA}

Women. Analysis of the change in the percentage of pilots who are women from 1978 to 1988 may offer a brief historical perspective. Table 1 will compare the ratios of female to male FAA pilot certificate holders from 1978 to 1988. This information is not released by the FAA until June 30th of the following year and distributed by the Government Printing office later in the year. Consequently, 1988 information is the most recent data which may be evaluated. 
Table 1

Total FAA Certificated Pilots

$\underline{1978}$

Certificates

Held

\begin{tabular}{|l|r|r|}
\hline \multicolumn{1}{|c}{} & \multicolumn{1}{c}{ Held } & Percentage \\
\hline Female & 49,874 & $6.25 \%$ \\
\hline Total & 748,959 & $93.75 \%$ \\
\hline
\end{tabular}

$\underline{1988}$

Certificates

Held Percentage

\begin{tabular}{||l|r|r||}
\hline Female & 42,297 & $6.09 \%$ \\
\hline Male & 651,717 & $93.91 \%$ \\
\hline Total & 694,016 & $100.00 \%$ \\
\hline
\end{tabular}

Source. U.S. Civil Airmen statistics.

While the last ten years have seen advances in opportunities available to women, progress has not been evidenced in all piloting careers. Table 2 provides a detailed distribution of each FAA certificate category by gender. Both non-flight and flight categories are presented. A comparison between the current data and that from ten years previous is rendered.

Table 2

Female FAA Certificate Holders

\begin{tabular}{||r|r|r||}
\multicolumn{1}{c}{ Category } & 1978 & 1988 \\
\hline Student & 26,354 & 17,529 \\
\hline Private & 19,147 & 17,544 \\
\hline Commercial & 3,306 & 4,410 \\
\hline ATP & 270 & 1,745 \\
\hline FE & 82 & 822 \\
\hline CFI & 1,458 & 3,018 \\
\hline A\&P & 597 & 2,565 \\
\hline
\end{tabular}

Source. U.S. Civil Airmen Statistics.

Although percentages of certificated women pilots are widely disproportionate, higher education is one area where women are experiencing gains toward achieving a proportionate role. One U.S. Department of Education report states that "women will be earning more doctoral degrees than men by the year 2000." (Projections, 1989). Table 3 shows the current gender distribution of women in 
the higher education faculty. A comparison is offered between private and public institutions.

Table 3

Faculty Distribution by Gender

Female $\%$

Male \&

\begin{tabular}{||l|l|l|l|}
\hline Public & 28.1 & 71.9 & $(100 \%)$ \\
\hline Private & 27.9 & 72.1 & $(100 \%)$ \\
\hline Median & 28.0 & 72.0 & $(100 \%)$ \\
\hline
\end{tabular}

Source. The Chronicle of Higher Education Almanac 1989.

Most fields within higher education are experiencing gains in the number of women who are receiving doctoral degrees. Within the discipline of education, this figure has surpassed 50 percent. Since there are no doctoral degrees solely devoted to aviation aside from aerospace engineering, Table 4 illustrates the number of women receiving doctoral degrees in fields related to aviation.

Table 4

Percentage of Women Receiving Doctorates in Aviation Related Fields

\begin{tabular}{||l|c|}
\hline Business & 23.4 \\
\hline Education & 55.1 \\
\hline Engineering & 6.5 \\
\hline Median All Fields & 35.2 \\
\hline
\end{tabular}

Source. The Chronicle of Higher Education Almanac 1989.

The final data to be presented on the demographics of the women faculty are the results from a survey of the 69 baccalaureate-level aviation education programs which was previously described. The information obtained through the survey offers two new sets of descriptive data about the status of these programs. First, it provides a measurement of the overall size of the faculty in baccalaureate-level aviation institutions. Secondly, the data provides the gender distribution of that group of faculty. The information provided in Table 5 describes the gender distribution of aviation faculty. 
Table 5

Gender Distribution of Aviation Faculty

\begin{tabular}{||l|c|c|}
\multicolumn{1}{c}{ Gender } & Number & Percentage \\
\hline Female & 25 & $(5.2 \%)$ \\
\hline Male & 456 & $(94.8 \%)$ \\
\hline Total & 481 & $(100.0 \%)$ \\
\hline
\end{tabular}

March 1990.

Minorities. Truly unfortunate is the fact that pilot certification data is not maintained by ethnic origin. If this data were available, analysis of minority participation in aviation fields requiring FAA certification could be measured and evaluated. Without this data, analysis of minority participation in the higher education aviation faculty will be compared to minority participation in the overall higher education faculty. Table 6 displays the distribution of the higher education faculty by minority and majority ethnic group.

\section{Table 6}

Faculty Distribution by Minority/Majority Ethnic Group

\begin{tabular}{||l|c|c|}
\multicolumn{1}{l}{ Group } & Number & Percentage \\
\hline Majority & 417,036 & $(89.9 \%)$ \\
\hline Minority & 47,036 & $(10.1 \%)$ \\
\hline Total & 464,072 & $(100.0 \%)$ \\
\hline
\end{tabular}

Source. Digest of Education Statistics 1989.

As previously explained, there are no doctoral degree programs exclusively oriented toward aerospace studies at the present time. Therefore, Table 7 will present the percentage of minorities receiving doctorates in aviation related fields. 
Table 7

Percentage of Minorities Receiving

Doctorates in Aviation Related Fields

\begin{tabular}{||l|c|}
\hline Business & 8.3 \\
\hline Education & 11.9 \\
\hline Engineering & 8.8 \\
\hline Median All Fields & 8.8 \\
\hline
\end{tabular}

Source. Digest of Education Statistics 1989.

Table 8 describes the current state of minority representation in the aviation faculty. This information was gathered through the previously described study of 69 baccalaureate degree granting institutions with aviation education programs. The significance of this demographic data arises from the fact that a benchmark has now been established from which to measure future progress in the encouragement of minorities to become collegiate aviation educators.

Table 8

Minority Representation in the Aviation Faculty

\begin{tabular}{||l|c|c|}
\multicolumn{1}{c|}{ Group } & Number & Percentage \\
\hline Minority & 38 & $(8.0 \%)$ \\
\hline Non-Minority & 443 & $(92.0 \%)$ \\
\hline Total & 481 & $(100.0 \%)$ \\
\hline
\end{tabular}

March 1990.

CONCLUDING DATA OBSERVATIONS

Women. Having discovered that only 5.2 percent of the collegiate aviation faculty consists of women, the question of why must be considered. After reviewing Table 3 which shows faculty distribution by gender, we can see that the percentage of overall faculty which are women $(28 \%)$ is not relational to the percentage of aviation faculty which are women (5.2\%). This fact demonstrates that the aviation faculty is not representative of the national norm with respect to the percentage of faculty which are women. 
Table 4, which exhibits data on the percentage of women receiving doctorates in aviation related fields, does not have a median (35.2\%) which corresponds with the percentage of aviation faculty that are women (5.2\%). However, the field of engineering which has a percentage of 6.5 percent of earned doctorate recipients being women is close to the percentage of women in the aviation faculty (5.2\%). Since aviation is perceived to be a high technology field, it could be possible that these two figures have a relational tie.

Another comparison of research data is that between the percentage of women aviation faculty and the percentage of women who are pilots. Table 1 presents the fact that 6.09 percent of FAA certificated pilots in 1988 were women. When you compare this with the fact that 5.2 percent of aviation faculty are women (Table 5) an obvious relationship can be seen. The percentage of women faculty and women pilots is very similar. This bit of data may suggest that women faculty in higher education is representative of the demonstrated interest that women have in aviation. If so, it could be stated that the problem is not only that women are under represented in the aviation faculty ranks, but the problem is that women are under represented in aviation as a whole.

Another figure which offers significant correlation to the percentage of women faculty and overall women pilots is the percentage of women who are certified Flight Instructors. In 1988 the U.S. Civil Airmen statistics reported that 5 percent of FAA Certified Flight Instructors were women. Being close to the 5.2 percent of women aviation faculty figure may indicate a correlation. The basis for this relationship could be reasoned through the fact that the certified Flight Instructor rating is held by those who become pilot educators. Furthermore, the Flight Instructor certificate acts as the terminal flight rating for most aviation educators.

Minorities. The median level of minority participation in the higher education faculty was shown in Table 6 to be 10.1 percent. This figure exceeds the current median of minorities receiving doctorates in all fields of higher education, 8.8 percent (Table 7). This fact should be of concern as we strive to achieve a greater level of participation by minorities in higher education. Two aviation related fields are experiencing a slightly above average participation by minorities. The fields are education (11.98) and engineering (9.4\%), as exhibited in Table 7 .

Data presented in Table 8 measured the level of participation of minorities who are collegiate aviation educators as 8.0 percent. This figure represents 38 of 481 individuals. Consequently, the fact can be observed that collegiate aviation education is below the national norm of 8.8 percent in minority participation in 
higher education. This difference is significant in that striving to meet the national norm would still demonstrate an under representation of minorities in the population of collegiate aviation educators.

\section{RECOMMENDATIONS: A CALL TO ACTION}

Concern for the under representation of women and minorities in the aviation faculty of higher education is overshadowed by concern for the under representation of women and minorities in all of aviation. Hopefully, the data presented within this study provides recognition that the participation levels of women and minorities in the aviation faculty is inadequate and must be challenged. The resulting call to action must be to take all possible steps to increase the number of women and minority ranks of collegiate aviation educators.

The recommendations offered are not comprehensive toward the solution of the problem considered herein. However, they should offer insight toward a starting point for the solution of the problem of under representation by women and minorities in the collegiate aviation faculty. They are as follow: (1) Recruit women and minority aviation faculty to foster role models. Increase the number of women and minority aviation students. (3) Work toward a means to facilitate more women and minorities to become pilots. (4) Solicit assistance from women and minority aviation organizations. (5) Encourage the aviation industry to hire more women and minorities. (6) Decrease stereotypical barriers to aviation which face women and minorities. Synthesize the aviation public to the problem. (8) Develop more coordinated graduate programs in aviation.

\section{REFERENCES}

Beardsley, P. (1990, August). [Interview with Pat Beardsley, statistician, Management standards and Statistics Division (AMS420) Federal Aviation Administration]. Washington, DC.

Digest of Education Statistics 1989. (1989). Washington, DC: U.S. Department of Education.

Flowers, S.F. (N.D.) - Women in Aviation and Space. Alabama, Ozark: Alabama Aviation and Technical College.

Gwaltney, c. (Ed.). (1989). The Chronicle of Higher Education Almanac.

Hadden, E. (1990, August). [Interview with Eddy Hadden, Organization of Black Airline Pilots]. New York, NY. 
Mazor, J. (1990, August). [Interview with John Mazor, Air Line Pilots Association]. Herndon, VA.

More student pilots. (1990, January 8). Aviation Week and Space Technology, p. 13 .

Newitt, J. (1989, November). Gray skies forever? American Demographics, pp. 37-39.

Projections of Education statistics to 2000. (1989). Washington, DC: U.S. Department of Education.

U. S. Civil Airmen Statistics. (1978). Washington, DC: Federal Aviation Administration.

U. S. Civil Airmen Statistics. (1988). Washington, DC: Federal Aviation Administration. 